\title{
Strengthening die-cast Al-Mg and Al-Mg-Mn alloys with Fe as a beneficial element
}

Xiangzhen Zhu ${ }^{\mathrm{a}}$, Paul Blake ${ }^{\mathrm{b}}$, Shouxun $\mathrm{Ji}^{\mathrm{a}^{*}}$

${ }^{a}$ Brunel Centre for Advanced Solidification Technology (BCAST), Institute of Materials and Manufacturing, Brunel University London, Uxbridge, Middlesex UB8 3PH, United Kingdom ${ }^{\mathrm{b}}$ Engineering Centre, Jaguar Land Rover, Abbey Road, Coventry, CV34 4LF, United Kingdom * Corresponding author: Tel.: +44 1895 266663, Fax: +44 1895 269758, Email: shouxun.ji@brunel.ac.uk

\begin{abstract}
The effect of $\mathrm{Fe}$ and $\mathrm{Mn}$ on the microstructure and mechanical properties of a series of Al$5 \mathrm{wt} . \% \mathrm{Mg}$ alloys processed by high pressure die casting (HPDC) was investigated. The Calculation of Phase Diagrams modelling (CALPHAD) was also carried out to understand the phase formation in experimental alloys. The results show that Fe can be a beneficial element in the Al-Mg and Al-Mg-Mn alloys to improve the mechanical properties. Fe only exists in the form of equilibrium $\mathrm{Al}_{13} \mathrm{Fe}_{4}$ phase in $\mathrm{Al}-\mathrm{Mg}-\mathrm{Fe}$ alloys. While, the addition of $0.6 \mathrm{wt} . \% \mathrm{Mn}$ suppresses the formation of equilibrium $\mathrm{Al}_{13} \mathrm{Fe}_{4}$ phase. In $\mathrm{Al}-\mathrm{Mg}-\mathrm{Mn}-\mathrm{Fe}$ alloys, all Fe-rich intermetallics is $\mathrm{Al}_{6}(\mathrm{Fe}, \mathrm{Mn})$ phase when Fe level is less than $2.5 \mathrm{wt} . \%$. When further increasing the $\mathrm{Fe}$ level, the primary non-equilibrium $\mathrm{Al}_{6}(\mathrm{Fe}, \mathrm{Mn})$ phase gradually evolves to form equilibrium $\mathrm{Al}_{13} \mathrm{Fe}_{4}$ phase, but the eutectic phase is still $\mathrm{Al}_{6}(\mathrm{Fe}, \mathrm{Mn})$. It was also found that both the eutectic $\mathrm{Al}_{13} \mathrm{Fe}_{4}$ in $\mathrm{Al}-\mathrm{Mg}-\mathrm{Fe}$ alloys and eutectic $\mathrm{Al}_{6}(\mathrm{Fe}, \mathrm{Mn})$ in $\mathrm{Al}-\mathrm{Mg}-\mathrm{Mn}-\mathrm{Fe}$ alloys are divorced in the eutectic phases as the primary Fe-rich phases appear. The Fe-rich intermetallic significantly affect the mechanical properties of experimental alloys. Fe enhances the yield strength obviously but reduces the elongation significantly. The ultimate tensile strength is also improved by $\mathrm{Fe}$ addition when Fe level is less than $2.0 \mathrm{wt} . \%$, but it is significantly decreased with further increasing the Fe level. Moreover, the Mn addition is found to increase the volume of strengthening Fe-rich intermetallic and thus can further strengthen $\mathrm{Al}-\mathrm{Mg}$ alloys.
\end{abstract}

\section{Key words:}

Aluminium alloys; Microstructure; Mechanical properties; Fe-rich compounds; High pressure die casting 


\section{Introduction}

The interest to use more recycled aluminium alloys is continuously growing because not only the economic, but also the environmental and social benefits can be obtained from the application of scrapped aluminium materials [1,2]. However, different inclusions and unwanted elements have been found in the recycled aluminium alloys, which are detrimental for the mechanical properties of fabricated products $[3,4]$. Of which, iron is the most concerned impurity element in the recycled aluminium alloys [5,6]. It is generally believed that the detrimental effect is due to its low equilibrium solubility in the $\alpha$-Al solid phase $(<0.04 \mathrm{wt} \%$ [7]) and the associated strong tendency to form various low symmetry Al-Fe or Al-Fe-Si intermetallic phases $[8,9]$. When these low symmetry compounds crystallise as primary phases during solidification, they are prone to grow into long needles/plates. As the Fe-rich intermetallics are generally brittle and act as stress raisers to weaken the coherence, they reduce the mechanical properties of aluminium alloys. Generally, the detrimental effect of Fe-rich intermetallic phases on the mechanical properties of aluminium alloys depends on their type, size and amount in the microstructure $[10,11,12]$.

In order to eliminate the detrimental effect of iron in aluminium alloys, several metallurgical solutions have been effectively used [13], which include (1) to avoid the formation of low symmetry Al-Fe or Al-Fe-Si compounds by lowering the Fe levels as low as economically possible; (2) to modify the crystal structures from low symmetry compounds to high symmetry lattice types in castings; (3) to refine the intermetallics by physical approaches including the use of superheated melt, solidification under high cooling rate, and/or melt treatment [14], or by chemical approaches to add $\mathrm{Ca}$ or $\mathrm{Sr}$ elements prior to solidification [15]; and (4) to spheroidise the needle or plate-shaped Fe-rich intermetallics using non-equilibrium heat treatment of castings [16]. However, there is limited study to use iron as a beneficial element to develop engineering capable alloys for industry.

Al-Mg alloys are attractive because of the properties/cost effectiveness recognized through the excellent corrosion resistance, weldability, formability, reliable manufacturing process, and ensuring at least $10 \%$ lower production costs in respect to the other suitable Al-alloys $[17,18]$. The magnesium in commercial aluminium alloys ranges all the way from 0.5 to $12-13 \% \mathrm{Mg}$, the low-magnesium alloys offer the best formability in wrought alloys while the highmagnesium alloys have reasonably good castability. It is generally believed that cast $\mathrm{Al}-\mathrm{Mg}$ 
alloys are able to provide excellent ductility [19]. Extensively researches have been made in wrought alloys and cast alloys to improve the mechanical properties and to extend the application of Al-Mg alloys [20]. It is normal practice to prepare Al-Mg alloys from the higher grades of aluminium to obtain maximum corrosion resistance and reflectivity thus the iron and silicon contents are usually lower than in other aluminium alloys [21]. However, in many applications, strength with acceptable ductility are more preferred for cast Al-Mg alloys, in particular when recycled materials is considered in production. Therefore, iron and other element such as zirconium can be added to increase the recrystallization temperature for eliminating the problems of these alloys [22]. Recently, iron was found to be able to increase the yield strength with the scarifying the ductility of die-cast alloys [23]. This could be a particularly positive signal to use iron as a beneficial element in $\mathrm{Al}-\mathrm{Mg}$ alloys to improve the yield strength and eliminate the tendency of super-plasticity, resulting the formation of reliable engineering alloys in casting industry. This could be a step change in both academic understanding and industrial application of recycled alloys.

Therefore, in the present study, the effect of iron on the microstructure and mechanical properties of $\mathrm{Al}-\mathrm{Mg}$ and $\mathrm{Al}-\mathrm{Mg}-\mathrm{Mn}$ alloys was investigated from experimental and from thermodynamic assessment. Cast alloys containing different levels of iron were processed with high pressure die casting. The as-cast microstructures were assessed by SEM and XRD for the phase distribution and phase constituent. The as-cast mechanical properties were measured and evaluated in association with the microstructure and phase constituent.

\section{Experimental}

The series of Al-5wt.\%Mg-xFe and Al-5wt.\%Mg-0.6 wt.\%Mn-xFe alloys ( $\mathrm{x}=0.5,1.0,1.5,2.0$, 2.5, 3.0 and 3.5) were prepared by melting commercial pure $\mathrm{Al}$ and $\mathrm{Mg}$ ingots, $\mathrm{Al}-20 \mathrm{Mn}$ and Al-45Fe master alloys (all compositions quoted in this paper are in wt.\% unless otherwise stated). Firstly, the pure Al got, Al-20 wt.\%Mn and Al-45 wt.\%Fe master alloys were melted in a clay-graphite crucible using an electric resistance furnace at $780{ }^{\circ} \mathrm{C}$. Then, pure $\mathrm{Mg}$ was added into the melt. To suppress the burning loss of $\mathrm{Mg}$ during experiment, $15 \mathrm{ppm} \mathrm{Be}$ was added into the melt. After a homogenization process for about $30 \mathrm{~min}$, degassing using commercial fluxes and $\mathrm{N}_{2}$ was performed. After that, the melt was manually dosed and subsequently released into the shot sleeve of a $4500 \mathrm{kN}$ cold chamber HPDC machine. The pouring temperature was controlled at $750{ }^{\circ} \mathrm{C}$. Eight ASTM standard tensile samples with 
$\phi 6.35 \mathrm{~mm}$ diameter were cast in each shot and the die was preheated by the circulation of mineral oil at $150^{\circ} \mathrm{C}$ in all casting trials.

The metallographic samples were cut from the middle of round ASTM standard samples with a $\Phi 6.35 \mathrm{~mm}$ and a gauge length of $50 \mathrm{~mm}$, and then mechanically ground and polished using standard method. To observe the 3D morphologies of the Fe-rich intermetallics in prepared Al$\mathrm{Mg}$ alloys, a $15 \mathrm{vol} \% \mathrm{HCl}$ distilled water solution was used to deep-etch or completely remove the matrix of the samples. The microstructure characterization and phase identification of the samples were carried out using X-ray diffraction (XRD, Rigaku D/max-rB, Japan) and scanning electron microscopy (SEM, Zeiss-Supra 35VP, Germany) equipped with energydispersive x-ray spectroscopy (EDS) and electron back-scattered diffraction (EBSD).

The composition of each alloy was analysed by optical emission spectrometer (OES, Foundrymaster Pro, UK), in which at least five spark analyses were performed, and the average value was taken as the chemical composition of alloy (shown in Table 1). All samples were kept at ambient condition for at least 3 days before the mechanical property test. The tensile tests were conducted using an Instron 5500 Universal Electromechanical Testing Systems at ambient temperature $\left(\sim 25^{\circ} \mathrm{C}\right)$ and a head-moving speed of $1 \mathrm{~mm} / \mathrm{min}$. For each alloy, at least 10 samples were tested and the average value of them was considered the mechanical properties of this alloy.

\section{Results}

\section{(a) Mechanical properties of Al-Mg-Fe and Al-Mg-Mn-Fe alloys}

The mechanical properties of the die cast Al-5wt.\%Mg-xFe and Al-5 wt.\%Mg-0.6 wt.\%Mn$\mathrm{xFe}(\mathrm{x}=0,0.5,1.0,1.5,2.0,2.5,3.0$ and $3.5 \mathrm{wt} . \%)$ alloys are presented in Figure 1. It is seen that the increase of Fe levels (from 0 to $3.5 \%$ ) in the experimental $\mathrm{Al}-5 \mathrm{Mg}-\mathrm{Fe}$ alloys induced a linear enhancement in the yield strength (from $126 \mathrm{MPa}$ to $154 \mathrm{MPa}$ ), but a significant decrement in the elongation (from $22.0 \%$ to $5.5 \%$ ). The ultimate tensile strength of $\mathrm{Al}-\mathrm{Mg}-\mathrm{Fe}$ alloys was also improved from $273 \mathrm{MPa}$ to $306 \mathrm{MPa}$ as the Fe levels was increased from 0 to $2.0 \%$. However further Fe addition is seriously detrimental to the ultimate tensile strength, which is only $269 \mathrm{MPa}$ when the Fe level reached $3.5 \%$. For the Al-5Mg-0.6Mn-Fe alloys, the Fe addition showed a similar effect on the elongation (decreased from $18.6 \%$ to $4.9 \%$ ), yield strength (increased from 146MPa to $155 \mathrm{MPa}$ ) and ultimate tensile strength (increased from 
$289 \mathrm{MPa}$ to $308 \mathrm{MPa}$ and then decreased to $273 \mathrm{MPa}$ ). It is also noticed that the strength of Al$5 \mathrm{Mg}-0.6 \mathrm{Mn}-\mathrm{Fe}$ alloy is higher than that of $\mathrm{Al}-5 \mathrm{Mg}-\mathrm{Fe}$ alloy when these two kinds of alloys have the same Fe level. Therefore, the strengthening by Fe is more effective in Al-5Mg- $0.6 \mathrm{Mn}$ alloy than that in $\mathrm{Al}-5 \mathrm{Mg}$ alloy. In the same time, the decrease of elongation is still not unacceptable when Fe is added at a level of $2 \mathrm{wt} . \%$. Therefore, Fe can be a benefit element in $\mathrm{Al}-\mathrm{Mg}$ and $\mathrm{Al}-\mathrm{Mg}-\mathrm{Mn}$ alloys for improving the strength. In order to understand the property improvement by Fe, the microstructures of $\mathrm{Al}-\mathrm{Mg}$ and $\mathrm{Al}-\mathrm{Mg}-\mathrm{Mn}$ alloys with different levels of $\mathrm{Fe}$ addition are studied.

\section{(b) Microstructures of Al-Mg-Fe and Al-Mg-Mn-Fe alloys}

Figure 2 shows the backscattered SEM micrographs of Al-5 wt.\% Mg (actual Fe level is 0.09 wt.\%\%) and Al-5 wt.\%Mg-0.6 wt.\%Mn (actual Fe level is 0.10 wt.\%\%) alloys. As observed, when Fe level was very low, these two alloys mainly consisted of $\alpha$-Al grains with minor intermetallics and porosities. In the Al-5wt. $\% \mathrm{Mg}$ alloy with little Fe (0.09 wt.\%\%), a few fine intermetallics located at the boundary of $\alpha$-Al grains were identified as $\mathrm{Al}_{13} \mathrm{Fe}_{4}$ (Figure 2b). In the Al-5 wt.\%Mg-0.6 wt.\%Mn alloy with little Fe (0.10 wt.\%\%), the intermetallics were identified as $\mathrm{Al}_{6}(\mathrm{Fe}, \mathrm{Mn})$ (Figure 2d). Although these two types of intermetallics showed slightly different morphologies, both were very fine. The $\mathrm{Al}_{13} \mathrm{Fe}_{4}$ phase was $3.5 \mu \mathrm{m}$ and the $\mathrm{Al}_{6}(\mathrm{Fe}, \mathrm{Mn})$ phase was $9.7 \mu \mathrm{m}$. Moreover, although $\mathrm{Al}-5 \mathrm{wt} . \% \mathrm{Mg}$ and $\mathrm{Al}-5$ wt. $\% \mathrm{Mg}-0.6$ wt. $\% \mathrm{Mn}$ alloys contained $5 \mathrm{wt} . \% \% \mathrm{Mg}$, no $\mathrm{Mg}$-rich intermetallic phase was found in the ascast microstructure. The EDS analysis results in Figure 3 confirmed that $5.13 \mathrm{wt} . \% \mathrm{Mg}$ was found in the $\mathrm{Al}$ matrix. This revealed that all $\mathrm{Mg}$ atoms were dissolved into $\alpha$ - $\mathrm{Al}$ grains.

The as-cast microstructures of Al-5 wt.\%Mg-xFe alloys ( $\mathrm{x}=0.5,1.5,2.5$ and 3.5 wt.\%) are shown in Figure 4 and the XRD of these alloys are shown in Figure 5. According to the XRD patterns, all Fe-rich intermetallic compounds in the alloys were identified as $\mathrm{Al}_{13} \mathrm{Fe}_{4}$ phase. Obviously, the Fe levels have determinant effects on the as-cast microstructure. With the increase of Fe level, the bright Fe-rich intermetallic particles which were identified as $\mathrm{Al}_{14} \mathrm{Fe}_{3}$ phase (also named as $\mathrm{Al}_{3} \mathrm{Fe}$ phase) by XRD (Figure 4a) became more and more. In the alloy with $0.5 \mathrm{wt}$.\% Fe, only regular eutectic $\mathrm{Al}_{14} \mathrm{Fe}_{3}$ phase was existed in a lamellar shape, as shown in Figure 4b. When the Fe level was increased to $1.5 \mathrm{wt} . \%$, in addition to the lamellar eutectic $\mathrm{Al}_{14} \mathrm{Fe}_{3}$, lath-like primary $\mathrm{Al}_{14} \mathrm{Fe}_{3}$ intermetallic compounds were also observed, as shown in Figure 4c. It was reported that the 3D morphology of $\mathrm{Al}_{13} \mathrm{Fe}_{4}$ is plate-like [24]. Our results were similar to the previous observation. As the increase of Fe level to $2.5 \mathrm{wt} . \%$ and $3.5 \mathrm{wt} . \%$, 
the amount of primary $\mathrm{Al}_{14} \mathrm{Fe}_{3}$ phase was further increased. In the alloy with $3.5 \mathrm{wt} \% \mathrm{Fe}$, some primary $\mathrm{Al}_{14} \mathrm{Fe}_{3}$ intermetallics showed irregular blocky shape, as shown in Figure $4 \mathrm{~g}$. It was also noticed that the morphology of eutectic $\mathrm{Al}_{14} \mathrm{Fe}_{3}$ phase was also changed from lamella (marked as $\mathrm{E}_{1}$ ) in the alloys with $0.5 \mathrm{wt} . \% \mathrm{Fe}$ and $1.5 \mathrm{wt} . \% \mathrm{Fe}$ to fine rod (marked as $\mathrm{E}_{2}$ ) in the alloys with $2.5 \mathrm{wt} . \% \mathrm{Fe}$ and $3.5 \mathrm{wt} . \% \mathrm{Fe}$, as shown in Figure $4 \mathrm{~b}, \mathrm{~d}, \mathrm{f}$ and h. Different with the regular lamellar eutectic $\mathrm{Al}_{14} \mathrm{Fe}_{3}$ phase, the rod-like eutectic $\mathrm{Al}_{14} \mathrm{Fe}_{3}$ phase was likely formed as a result of divorce from $\alpha-\mathrm{Al}$ phase.

It should be mentioned that the primary $\mathrm{Al}_{14} \mathrm{Fe}_{3}$ compounds in alloys with $2.5 \mathrm{wt} . \% \mathrm{Fe}$ and 3.5 wt. $\% \mathrm{Fe}$ have two notably different sizes marked as $\mathrm{Fe}_{1}$ for the coarsen one and $\mathrm{Fe}_{2}$ for the fine one in Figure $4 \mathrm{e}$ and $\mathrm{g}$. The formation of these two kinds of primary $\mathrm{Al}_{14} \mathrm{Fe}_{3}$ intermetallics has a close relation with the two-step solidification during cold-chamber HPDC process [6]. When the melt was released into the shot sleeve, partial melt which touched the shot sleeve would start the first solidification immediately under a cooling rate of about $10^{2} \mathrm{~K} / \mathrm{s}$. Therefore, some primary $\mathrm{Al}_{14} \mathrm{Fe}_{3}$ intermetallics (marked as $\mathrm{Fe}_{1}$ ) precipitated from the melt and grew rapidly in the shot sleeve before being pushed into the die cavity. After a few seconds (usually less than $5 \mathrm{~s}$ ), the melt mixture was pushed into the die cavity and the subsequent solidification (referred as secondary solidification in ref. [25]) occurred under a high pressure (300 to 600bar) and high cooling rate over $10^{3} \mathrm{~K} / \mathrm{s}$. This high cooling rate increased the super cooling degree and thus triggered more nucleation events, which led to the formation of fine $\mathrm{Fe}_{2}$ phase. Meanwhile, the $\mathrm{Fe}_{1}$ intermetallics precipitated in shot sleeve would be separated and dispersed into the melt, which could act as the site for secondary solidification to obtain a further growing in die cavity. The as-cast microstructures of Al-5 wt.\%Mg-0.6wt.\%Mn-xFe alloys ( $\mathrm{x}=0.5,1.5,2.5$ and 3.5 wt.\%) are shown in Figure 6 and the XRD of these alloys are shown in Figure 7. According to the XRD patterns, all Fe-rich intermetallic compounds in the alloys with $0.5 \mathrm{wt} . \% \mathrm{Fe}$ and 1.5 wt. $\%$ Fe were identified as $\mathrm{Al}_{6}(\mathrm{Fe}, \mathrm{Mn})$ phase, while both $\mathrm{Al}_{6}(\mathrm{Fe}, \mathrm{Mn})$ and $\mathrm{Al}_{13} \mathrm{Fe}_{4}$ phases were found in the alloys with $2.5 \mathrm{wt} . \% \mathrm{Fe}$ and $3.5 \mathrm{wt} . \% \mathrm{Fe}$. From Figure 6, it is seen that the morphology, size and amount of Fe-rich phase changed obviously as the increase of Fe levels. In the alloy with $0.5 \mathrm{wt} . \% \mathrm{Fe}$, eutectic $\mathrm{Al}_{6}(\mathrm{Fe}, \mathrm{Mn})$ were located at the grain boundaries and showed a lamellar morphology (marked as ' $\mathrm{E}_{1}$ '), as shown in Figure $6 \mathrm{a}$ and $\mathrm{b}$. When the Fe level was at $1.5 \mathrm{wt} . \%$, the rhombic or lath-like primary $\mathrm{Al}_{6}(\mathrm{Fe}, \mathrm{Mn})$ phase was found in Figure 6c. Meanwhile, the eutectic $\mathrm{Al}_{6}(\mathrm{Fe}, \mathrm{Mn})$ intermetallics were divorced from $\alpha-\mathrm{Al}$ phase and exhibited as fine lath-like or rhombic morphologies with faceted surface (Figure 6d, marked as ' $\mathrm{E}_{2}$ '). When the Fe level was further increased to $2.5 \mathrm{wt} . \%$, both the amount and size of primary 
$\mathrm{Al}_{6}(\mathrm{Fe}, \mathrm{Mn})$ intermetallics were increased, and irregular blocky primary $\mathrm{Al}_{13} \mathrm{Fe}_{4}$ intermetallics were also formed, as shown in Figure $6 e$ and $\mathrm{f}$. In the alloy with $3.5 \mathrm{wt} . \%$ Fe (Figure $6 \mathrm{~g}$ and $\mathrm{h}$ ), the blocky $\mathrm{Al}_{13} \mathrm{Fe}_{4}$ became the dominate primary phase, while the eutectic phase was still the $\mathrm{Al}_{6}(\mathrm{Fe}, \mathrm{Mn})$ phase (marked as $\left.\mathrm{E}_{2}\right)$. Moreover, it was noticed that the primary Fe-rich intermetallics in the alloys with $2.5 \mathrm{wt} . \% \mathrm{Fe}$ and $3.5 \mathrm{wt} . \% \mathrm{Fe}$ also showed two different size ranges (marked as ' $\mathrm{Fe}_{1}$ ' for coarsen ones and ' $\mathrm{Fe}_{2}$ ' for fine ones). Similar with the two types of primary Fe-rich phase in the $\mathrm{Al}-\mathrm{Mg}-\mathrm{Fe}$ alloys, the primary $\mathrm{Fe}_{1}$ and $\mathrm{Fe}_{2}$ intermetallics in the Al-Mg-Mn-Fe alloys also precipitated in the first solidification and the secondary solidification during cold-chamber HPDC process, respectively.

As mentioned above, both the primary and eutectic $\mathrm{Al}_{6}(\mathrm{Fe}, \mathrm{Mn})$ intermetallics in alloys $1.5 \mathrm{wt} . \% \mathrm{Fe}$ and $2.5 \mathrm{wt} . \% \mathrm{Fe}$ showed two 2D faceted morphologies: rhombus and lath. This result is in good agreement with the existing literature[26]. It was also noticed that almost each primary $\mathrm{Al}_{6}(\mathrm{Fe}, \mathrm{Mn})$ had an inside hollow, which was different with the normal solid primary phase in alloys. However, the 3D morphology of $\mathrm{Al}_{6}(\mathrm{Fe}, \mathrm{Mn})$ phase has not been reported. To observe the $3 \mathrm{D}$ morphology of $\mathrm{Al}_{6}(\mathrm{Fe}, \mathrm{Mn})$ phase, the $\mathrm{Al}_{6}(\mathrm{Fe}, \mathrm{Mn})$ intermetallics were extracted from the alloys by a $15 \% \mathrm{HCl}$ water solution. Figure 8 shows that both the primary and eutectic $\mathrm{Al}_{6}(\mathrm{Fe}, \mathrm{Mn})$ intermetallics have a same 3D morphology: quadrangular prism. The difference was that the large primary $\mathrm{Al}_{6}(\mathrm{Fe}, \mathrm{Mn})$ phase was in hollow shape, while the small eutectic $\mathrm{Al}_{6}(\mathrm{Fe}, \mathrm{Mn})$ phase was in a solid shape. It can be inferred that the rhombus and lath shapes observed in Figure 6 were the 2D polygonal sections of quadrangular prism cut at random angles.

A distinguished advantage of HPDC is the high cooling rate during solidification process, which leads to the formation of fine $\alpha$-Al grains. In the present work, no significant difference was found in the size and morphologies of the primary $\alpha-\mathrm{Al}$ phase in the experimental $\mathrm{Al}-\mathrm{Mg}$ alloys containing different levels of $\mathrm{Mn}$ and $\mathrm{Fe}$. The sizes of $\alpha$-Al grains were analysed using EBSD technology, and the typical size distribution is shown in Figure 9. Similar with the Ferich intermetallics, $\alpha$-Al solid solution also showed two size ranges. Most $\alpha$-Al grains were fine globular particles with a size of less than $20 \mu \mathrm{m}$ (marked as $\alpha_{1}$ ), while there also existed a few large dendritic and fragmented dendritic $\alpha$-Al phases ranged from 20 to $100 \mu \mathrm{m}$. The coarsened $\alpha-\mathrm{Al}$ phase was isolated by fine globular $\alpha$-Al particles (marked as $\alpha_{2}$ ). The formation of these two kinds of $\alpha$-Al phase is also induced by the two-step solidification during cold-chamber HPDC process. 


\section{(c) CALPHAD of the multi-component Al-Mg-Fe and Al-Mg-Mn-Fe systems}

In order to understand the effect of Fe and $\mathrm{Mn}$ on solidification and microstructural evolution, CALPHAD modelling of the multicomponent Al-Mg-Fe and Al-Mg-Mn-Fe systems was carried out using Pandat software. The calculated equilibrium phase diagrams on the cross sections of $\mathrm{Al}-5 \mathrm{Mg}-\mathrm{xFe}$ and $\mathrm{Al}-5 \mathrm{Mg}-0.6 \mathrm{Mn}-\mathrm{xFe}$ are shown in Figure 10.

According to the calculated equilibrium diagram shown in Figure 10a, the liquid-solid solidification reactions of the $\mathrm{Al}-5 \mathrm{Mg}-\mathrm{xFe}$ alloy occurred at more than $550^{\circ} \mathrm{C}$ and could be described as follows: (1) when Fe level $<0.93 \%, \mathrm{~L} \rightarrow \mathrm{L}+\alpha-\mathrm{Al}_{\mathrm{P}} \rightarrow \alpha-\mathrm{Al}_{\mathrm{P}}+\left(\alpha-\mathrm{Al}+\mathrm{Al}_{13} \mathrm{Fe}_{4}\right)_{\mathrm{E}}$, (2) when $\quad \mathrm{Fe}$ level $>0.93 \%, \quad \mathrm{~L} \rightarrow \mathrm{L}+\mathrm{Al}_{13} \mathrm{Fe}_{4 \mathrm{P}} \rightarrow \mathrm{Al}_{13} \mathrm{Fe}_{4 \mathrm{P}}+\left(\alpha-\mathrm{Al}+\mathrm{Al}_{13} \mathrm{Fe}_{4}\right)_{\mathrm{E}}$. The subscript $\mathrm{P}$ represented the primary particles and E represents the eutectic crystals. When the temperatures were decreased below $270^{\circ} \mathrm{C}, \beta$-AlMg phase precipitated in all experimental alloys by a solidsolid reaction.

After the addition of $\mathrm{Mn}$ into Al-Mg-Fe system, the calculated equilibrium diagram became a little complex. According the diagram shown in Figure 10b, the equilibrium microstructure of Al-5wt.\%Mg-0.6wt.\%Mn-xFe alloys should have following features: (1) only when $\mathrm{Fe}$ level $<0.1 \%$, the eutectic $\mathrm{Al}_{6}(\mathrm{Fe}, \mathrm{Mn})$ was the only Fe-rich intermetallic; (2) when $\mathrm{Fe}$ level $>0.1 \%$, the eutectic $\mathrm{Al}_{6}(\mathrm{Fe}, \mathrm{Mn})$ phase coexisted with the eutectic $\mathrm{Al}_{13} \mathrm{Fe}_{4}$ phase; (3) when Fe level $>0.68 \%$, primary $\mathrm{Al}_{13} \mathrm{Fe}_{4}$ phase also formed and was the only primary phase in alloys. Besides, $\beta$-AlMg phase should precipitate in all experimental alloys by solid-solid reactions when temperature was below $270^{\circ} \mathrm{C}$.

However, it was found the as-cast microstructures of experimental $\mathrm{Al}-\mathrm{Mg}$ alloys and $\mathrm{Al}-\mathrm{Mg}-$ Mn-Fe alloy were not well consistent with the equilibrium phase diagram. The reason is attributed to the noon-equilibrium solidification in HPDC process, which will be discussed later in this paper.

\section{(d) Fractography of Al-Mg-Fe and Al-Mg-Mn-Fe alloys}

The tensile fracture analysis helps to understand the effects of $\mathrm{Fe}$ and $\mathrm{Mn}$ on the tensile properties of experimental alloys. As shown in Figures 11a and d, the fracture surfaces of Al5wt.\%Mg and Al-5 wt.\%Mg-0.6 wt.\% Mn alloys comprised a large population of tear ridges 
and dimples, which indicates that the alloys had very good ductility. The fracture surfaces of Al-5 wt.\%Mg-2.0 wt.\%Fe and Al-5 wt.\%Mg-0.6 wt.\%Mn-2.0 wt.\%Fe alloys also contained many dimples. However, these dimples had much smaller sizes and much higher number density compared with that in the alloys without Fe. At the bottom of the dimples, there often existed Fe-rich intermetallics with cracks. The insets in Figures $11 \mathrm{c}$ and $\mathrm{d}$ showed the cracked primary $\mathrm{Al}_{13} \mathrm{Fe}_{4}$ and primary $\mathrm{Al}_{6}(\mathrm{Fe}, \mathrm{Mn})$ particles, which featured the locally brittle failure. The small dimples and cracked intermetallics imply that the fracture of the alloys with $2.0 \mathrm{wt}$ \% Fe was a combination of dominated ductile fracture and a partial brittle fracture. In Al5 wt.\%Mg-3.5 wt.\%Fe and Al-5 wt.\%Mg-0.6 wt.\%Mn-3.5 wt.\%Fe alloys, many large cracked primary $\mathrm{Al}_{13} \mathrm{Fe}_{4}$ particles with cleavage facets and steps were found, as shown in Figure 11e and $\mathrm{f}$. It means the brittle fracture mechanism became more obvious as the increase of Fe levels.

\section{Discussion}

\section{(a) Phase formation in die cast Al-Mg-Fe and Al-Mg-Mn-Fe alloys}

Comparing the as-cast microstructures (Figures 2, 4 and 6) and equilibrium phase diagram (Figure 10), it was found the phase formation in the experimental Al-Mg-Fe and Al-Mg-MnFe alloys was not completely consistent with the prediction by the phase diagram. In both experimental Al-Mg-Fe and Al-Mg-Mn-Fe alloys, the equilibrium phase $\beta$-AlMg was not observed. In the experimental $\mathrm{Al}-\mathrm{Mg}-\mathrm{Mn}-\mathrm{Fe}$ alloys, the equilibrium eutectic $\mathrm{Al}_{13} \mathrm{Fe}_{4}$ phase also was not found. Moreover, when Fe level was less than $2.5 \mathrm{wt} . \%$, the equilibrium primary $\mathrm{Al}_{13} \mathrm{Fe}_{4}$ phase in $\mathrm{Al}-\mathrm{Mg}-\mathrm{Mn}-\mathrm{Fe}$ alloys was also replaced by non-equilibrium primary $\mathrm{Al}_{6}(\mathrm{Fe}$, $\mathrm{Mn})$ Phase. The above phenomena can be considered as the result of high cooling rate during HPDC process.

According to the calculated results by Pandat software, the $\beta$-AlMg phase forms by following solid-solid reactions: (1) $\alpha-\mathrm{Al} \rightarrow \mathrm{l}_{13} \mathrm{Fe}_{4}+\beta-\mathrm{AlMg}$ and (2) $\alpha-\mathrm{Al}+\mathrm{Al}_{13} \mathrm{Fe}_{4} \rightarrow \mathrm{Al}_{6}(\mathrm{Fe}, \mathrm{Mn})+\beta-\mathrm{AlMg}$. Because it is compositionally different to its surroundings, the new $\beta$-AlMg phase can only be formed by transporting atoms over relatively long distances. Obviously, the above reactions can be suppressed by quenching to low temperatures at which atomic diffusion is very slow. Therefore, due to the high cooling rate during HPDC process, the formation of $\beta$-AlMg phase is suppressed.

Phase competition is a common phenomenon in Al-Fe alloys and has been intensively studied. Generally, the high cooling rate is the trigger of the formation of metastable phase such as 
$\mathrm{Al}_{6} \mathrm{Fe}$ [17-20]. While, $\mathrm{Li}$ [26] reported that the addition of Mn induced the formation of primary $\mathrm{Al}_{6}(\mathrm{Fe}, \mathrm{Mn})$ phase in $\mathrm{Al}-2 \mathrm{wt} . \% \mathrm{Fe}$ alloy produced by a metal mould. It indicates that $\mathrm{Mn}$ benefits the formation of metastable $\mathrm{Al}_{6}(\mathrm{Fe}, \mathrm{Mn})$ phase. While, in the present HPDC Al5wt.\%Mg-0.6 wt.\%Mn-xFe alloys, it was also found that the equilibrium primary $\mathrm{Al}_{13} \mathrm{Fe}_{4}$ phase began to appear again when the Fe level was increased to $2.5 \mathrm{wt} . \%$, and then became the dominant primary phase when the Fe level was further increased to $3.5 \mathrm{wt}$.\%. This phenomenon shows that the beneficial effect of $\mathrm{Mn}$ on the formation of metastable $\mathrm{Al}_{6}(\mathrm{Fe}, \mathrm{Mn})$ phase was dependent upon the atomic ratio of $\mathrm{Mn}$ to Fe. High ratio favours the formation of metastable primary $\mathrm{Al}_{6}(\mathrm{Fe}, \mathrm{Mn})$ phase. Moreover, the eutectic $\mathrm{Al}_{13} \mathrm{Fe}_{4}$ phase was also observed in Li's experimental alloys, but was not observed in our HPDC samples. Therefore, it can be concluded that the high cooling rate during HPDC process is a critical factor to inhibit the formation of eutectic $\mathrm{Al}_{13} \mathrm{Fe}_{4}$ phase.

\section{(b) Effect of Mn on the volume of Fe-rich intermetallic}

$\mathrm{Al}_{13} \mathrm{Fe}_{4}$ and $\mathrm{Al}_{6}(\mathrm{Fe}, \mathrm{Mn})$ are the strengthening intermetallics in the experimental $\mathrm{Al}-5 \mathrm{wt} . \% \mathrm{Mg}$ $\mathrm{xFe}$ and Al-5wt.\%Mg-0.6 wt.\%Mn-xFe alloys. Thus, the volume of these intermetallics has a great influence on the mechanical properties of alloys. From Figures 3 and 5, it was found the addition of $0.6 \% \mathrm{Mn}$ can obviously increase the fraction of Fe-rich intermetallics in the alloys. This great change can be understood from two aspects. On one hand, the added $0.6 \mathrm{wt} . \% \mathrm{Mn}$ also forms Fe-rich intermetallics, therefore increases the volume of intermetallic phase for second phase strengthening. On the other hand, the difference in crystal structures of $\mathrm{Al}_{13} \mathrm{Fe}_{4}$ and $\mathrm{Al}_{6}(\mathrm{Fe}, \mathrm{Mn})$ phases also leads to an obvious volume change of Fe-rich intermetallics.

Figure 12 shows the crystal structure of $\mathrm{Al}_{13} \mathrm{Fe}_{4}$ and $\mathrm{Al}_{6}(\mathrm{Fe}, \mathrm{Mn})$ phases. For the convenience of presentation, the unit cell of $\mathrm{Al}_{13} \mathrm{Fe}_{4}$ and $\mathrm{Al}_{6}(\mathrm{Fe}, \mathrm{Mn})$ crystals were plotted at a similar size in Figure 12. However, they actually have very different sizes. As summarised in Table 2 for the crystal parameters of $\mathrm{Al}_{13} \mathrm{Fe}_{4}$ and $\mathrm{Al}_{6}(\mathrm{Fe}, \mathrm{Mn})$ cell. The $\mathrm{Al}_{13} \mathrm{Fe}_{4}$ unit cell has a monoclinic structure $\left(a=15.492 \AA, b=8.78 \AA, c=12.471 \AA\right.$ and $\left.\beta=107.69^{\circ}\right)$ and a cell volume of 1486.88 $\AA^{3}[27]$; while, the $\mathrm{Al}_{6}(\mathrm{FeMn})$ unit cell has an orthorhombic structure $(\mathrm{a}=7.498 \AA, \mathrm{b}=6.495 \AA$ and $\mathrm{c}=8.837 \AA$ ) and a cell volume of $430.36 \AA^{3}[28]$. The number of Fe or Mn atoms $\left(\mathrm{N}_{\mathrm{FeMn}}\right)$ is 20 in the $\mathrm{Al}_{13} \mathrm{Fe}_{4}$ unit cell, but is only 4 in the $\mathrm{Al}_{6}(\mathrm{Fe}, \mathrm{Mn})$ unit cell. Thus, it can be calculated that the average volume of Fe-rich intermetallic induced by each Fe or $\mathrm{Mn}$ atom $\left(\mathrm{V}_{\mathrm{FeMn}}\right)$ is only $74.34 \AA^{3}$ for the $\mathrm{Al}_{13} \mathrm{Fe}_{4}$, but reaches up to $107.59 \AA^{3}$ for the $\mathrm{Al}_{6}(\mathrm{Fe}, \mathrm{Mn})$. The experimental results have confirmed that the addition of $\mathrm{Mn}$ promotes the formation of $\mathrm{Al}_{6}(\mathrm{Fe}, \mathrm{Mn})$ but 
supresses the formation of $\mathrm{Al}_{13} \mathrm{Fe}_{4}$. After the phase transformation from $\mathrm{Al}_{13} \mathrm{Fe}_{4}$ to $\mathrm{Al}_{6}(\mathrm{Fe}, \mathrm{Mn})$ in Al-Mg alloys induced by $\mathrm{Mn}$, the volume of Fe-rich intermetallics increases up to 1.45 times. This change would subsequently affect the mechanical properties of alloys.

\section{(c) Microstructure-property relationship}

The microstructure analysis has confirmed that the experimental $\mathrm{Al}-\mathrm{Mg}-\mathrm{Fe}$ and $\mathrm{Al}-\mathrm{Mg}-\mathrm{Mn}-\mathrm{Fe}$ alloys consisted of Mg-rich $\alpha$-Al solution and Fe-rich intermetallics. The size distribution of $\alpha-$ $\mathrm{Al}$ grains in all experimental alloys is similar, meaning that the grain boundary strengthening effect for all alloys has no obvious difference. Moreover, the fact that no $\beta$-AlMg phase is observed indicates that the solution strengthening effect provided by $\mathrm{Mg}$ atoms is also very similar in all the experimental alloys. Therefore, it can be concluded that the Fe-rich intermetallics, which provide a second-phase strengthening, are the key to control the mechanical properties of experimental $\mathrm{Al}-\mathrm{Mg}-\mathrm{Fe}$ and $\mathrm{Al}-\mathrm{Mg}-\mathrm{Fe}-\mathrm{Mn}$ alloys.

Be different with the soft and ductile $\alpha$-Al phase, the Fe-rich intermetallics are very hard and brittle. Therefore, the Fe-rich intermetallics can act as pins to prevent dislocation from sliding under stress, which substantially improves the yield strength. However, due to the high local stress around Fe-rich intermetallics during tensile process, the brittle intermetallics are prone to initialise cracks, resulting in the reduction in ductility. Therefore, as the increase of amounts of Fe-rich intermetallics, the yield strength of experimental alloys is enhanced at the cost of scarifying the elongation, as shown in Figure 1. Meanwhile, as the origin of dimple, the more and more cracked Fe-rich intermetallics also results in more but smaller dimples on the fracture surface, as shown in Figure 11.

As the pin to inhibit the dislocation motion, the Fe-rich intermetallics can also improve ultimate tensile strength of alloys, as shown in Figure 1. However, if the size of brittle intermetallics is too large, it would have a detrimental effect on the ultimate tensile strength. During tensile test, alloys would undergo a period of obvious plastic deformation after the yield point. The plastic deformation will introduce new more dislocations and thus induce higher stress. In this case, the brittle Fe-rich intermetallics are easy to crack along definite crystallographic structural planes with low bonding (cleavage planes). If the size of Fe-rich intermetallics are too large, the cracks tend to expand quickly to reach a critical size, then the premature fracture occurs when the maximum stress is still not high, resulting a relative low ultimate strength. As seen in Figures 2, 4 and 6, only a few of primary Fe-rich intermetallic appeared in Al-Mg-Fe and 
Al-Mg-Mn-Fe alloys with $1.5 w t . \% F e$. Then as the further increase of Fe levels, both the size and amount of primary intermetallics are increased. The tensile test results (Figure 1) show that the ultimate strength of experimental alloys reaches the maximum value when Fe level increases to $2.0 \mathrm{wt} . \%$, but decreases as Fe level is further increased due to the appearance of lots of large Fe-rich intermetallics.

It is also noticed that, when the Fe level is at the same level, the Al-Mg-Mn-Fe alloy has a higher strength and a lower elongation than Al-Mg-Fe alloy. It is because the addition of $\mathrm{Mn}$ obviously increase the volume of strengthening Fe-rich intermetallics (especially the eutectic intermetallics). When Fe level in Al-Mg-Mn-Fe alloys is more than 2.0wt.\%, the primary phase evolves gradually to $\mathrm{Al}_{13} \mathrm{Fe}_{4}$ from $\mathrm{Al}_{6}(\mathrm{Fe}, \mathrm{Mn})$. In the view of crystal structure, $\mathrm{Al}_{13} \mathrm{~F}_{4}$ is more compact than $\mathrm{Al}_{6}(\mathrm{Fe}, \mathrm{Mn})$. Moreover, $\mathrm{Al}_{13} \mathrm{Fe}_{4}$ is in solid while primary $\mathrm{Al}_{6}(\mathrm{Fe}, \mathrm{Mn})$ is in hollow. So the phase evolution from $\mathrm{Al}_{6}(\mathrm{Fe}, \mathrm{Mn})$ to $\mathrm{Al}_{13} \mathrm{Fe}_{4}$ decreases the volume and size of primary Fe-rich intermetallics, thus reduces the deleterious effect of large primary Fe-rich intermetallics on the ultimate tensile strength. It ensures that the Al-Mg-Mn-Fe alloys still have a higher ultimate strength than Al-Mg-Fe alloys when Fe level is more than 2.0wt.\%.

It needs to emphasise that the application of $\mathrm{Fe}$ as a beneficial element in aluminium alloys for strengthening is dependent on several factors. (1) The aluminium alloys need to have sufficient ductility for scarification by the formation of Fe-rich intermetallics. (2) The Fe-rich intermetallics should be in a form of fine and compact. (3) The cooling rate during solidification needs to be sufficiently high to form fine primary aluminium phase and fine and compact $\mathrm{Fe}$ rich intermetallics. Therefore, $\mathrm{Al}-\mathrm{Mg}$ based alloys processed by high pressure die casting is a good option.

\section{Conclusion}

(1) In high pressure die casting of $\mathrm{Al}-\mathrm{Mg}$ and $\mathrm{Al}-\mathrm{Mg}-\mathrm{Mn}$ alloys, the addition of $\mathrm{Fe}$ is beneficial for increasing the yield strength and eliminating the tendency of superplasticity, resulting the formation of reliable engineering alloys.

(2) In the experimental $\mathrm{Al}-\mathrm{Mg}-\mathrm{Fe}$ alloys, Fe element only exists in the form of $\mathrm{Al}_{13} \mathrm{Fe}_{4}$ phase. After the addition of $0.6 \mathrm{wt} . \% \mathrm{Mn}$, the Fe element in Al-Mg-Mn-Fe alloys only forms $\mathrm{Al}_{6}(\mathrm{Fe}, \mathrm{Mn})$ phase when $\mathrm{Fe}$ level is less than $2.5 \mathrm{wt} . \%$. When the further increase of Fe level to $3.5 \mathrm{wt} . \%$, the primary phase gradually evolves to $\mathrm{Al}_{13} \mathrm{Fe}_{4}$ from $\mathrm{Al}_{6}(\mathrm{Fe}$, $\mathrm{Mn})$, but the eutectic phase still remains as $\mathrm{Al}_{6}(\mathrm{Fe}, \mathrm{Mn})$. 
(3) Both the eutectic $\mathrm{Al}_{13} \mathrm{Fe}_{4}$ in $\mathrm{Al}-\mathrm{Mg}-\mathrm{Fe}$ alloys and eutectic $\mathrm{Al}_{6}(\mathrm{Fe}, \mathrm{Mn})$ in $\mathrm{Al}-\mathrm{Mg}-\mathrm{Mn}-$ Fe alloys are divorced in the eutectic phases when the primary Fe-rich phases appear in the as-cast microstructure. The divorced eutectic $\mathrm{Al}_{6}(\mathrm{Fe}, \mathrm{Mn})$ and primary $\mathrm{Al}_{6}(\mathrm{Fe}$, $\mathrm{Mn}$ ) have the same morphology of quadrangular prism, but the eutectic phase is in hollow shapes and the primary phase is solid shapes.

(4) Fe-rich intermetallics significantly affect the mechanical properties of the alloy castings. The addition of $\mathrm{Fe}$ enhances the yield strength but reduces the elongation significantly. The ultimate tensile strength is also improved by Fe addition when Fe level is less than $2.0 \%$ but decreases significantly with the further increase of Fe level, implying that the Fe contents is better to controlled in a level between 2.0 to $2.5 \mathrm{wt} . \%$.

(5) The addition of Mn increases the volume of strengthening Fe-rich intermetallics, and thus further improve the strength of $\mathrm{Al}-\mathrm{Mg}$ alloys.

\section{Acknowledgements}

Financial support from Jaguar Range Rover (JLR) [grant number R33232] is gratefully acknowledged. 


\section{References}

[1 ]S Ji, W Yang, F Gao, D Watson, Z Fan, Effect of Iron in Al - Mg - Si - Mn Ductile Diecast Alloy, Light Metals 2013, 317-322

[2] J.A.S. Green, Aluminum recycling and processing for energy conservation and sustainability, ASM International, 2007.

[3] M.E. Schlesinger, Aluminum recycling, CRC Press, 2013.

[4] S.G. Shabestari, The effect of iron and manganese on the formation of intermetallic compounds in aluminum-silicon alloys, Mater. Sci. Eng. A. 383 (2004) 289-298.

[5] W Yang, S Ji, X Zhou, I Stone, G Scamans, GE Thompson, Z Fan, Heterogeneous Nucleation of $\alpha$-Al Grain on Primary $\alpha$-AlFeMnSi Intermetallic Investigated Using 3D SEM Ultramicrotomy and HRTEM, Metallurgical and Materials Transactions A 45, 2014, 3971-3980

[6] S Ji, H Yang, X Cui, Z Fan, Macro-heterogeneities in microstructures, concentrations, defects and tensile properties of die cast $\mathrm{Al}-\mathrm{Mg}-\mathrm{Si}$ alloys, Materials Science and Technology 33 (18), 2017, 2223-2233

[7] S. Ji, D. Watson, Z. Fan, M. White, Mater. Sci. Eng. A. 556(2012) 824-833.

[8] A. Couture, Iron in aluminum casting alloys-a literature survey, Int. Cast Met. J. 6 (1981) 9-17.

[9] L. Wang, D. Apelian, M.M. Makhlouf, Iron-bearing compounds in Al-Si diecasting alloys: morphology and vonditions under ehich they gorm (99-146), Trans. Am. Foundrymen's Soc. 107 (1999) 231-238.

[10] H Yang, S Ji, D Watson, Z Fan, Repeatability of tensile properties in high pressure diecastings of an Al-Mg-Si-Mn alloy, Metals and Materials International 21 (5), 2015, 936943

[11] W Yang, GAO Feng, S Ji, Formation and sedimentation of Fe-rich intermetallics in Al$\mathrm{Si}-\mathrm{Cu}-\mathrm{Fe}$ alloy, Transactions of Nonferrous Metals Society of China 25 (5), 1704-1714

[12] S Ji, D Watson, Z Fan, X-Ray Computed Tomographic Investigation of High Pressure Die Castings, Light Metals 2017, 861-866

[13] S Ji, W Yang, F Gao, D Watson, Z Fan, Effect of iron on the microstructure and mechanical property of $\mathrm{Al}-\mathrm{Mg}-\mathrm{Si}-\mathrm{Mn}$ and $\mathrm{Al}-\mathrm{Mg}-\mathrm{Si}$ diecast alloys, Materials Science and Engineering: A 564, 130-139

[14] X. Fang, G. Shao, Y.Q. Liu, Z. Fan, Mater. Sci. Eng. A 445-446 (2007) 65-72. 
[15] S. S. Kumari, R. M. Pillai, B. C. Pai, K. Nogita, A. K. Dahle, Metall. Mater. Trans. A 37A (2006) 2581-2587.

[16] L. A. Narayanan, F. H. Samuel, J. E. Gruzleski, Metall. Mater. Trans. A 26A (1995) 2161-2174.

[17] ENDRE ROMHANJI, MILJANA POPOVIĆ, PROBLEMS AND PROSPECT OF AlMg ALLOYS, APPLICATION IN MARINE CONSTRUCTIONS, Association of Metallurgical Engineers of Serbia, AME, p297-307

[18] Mirko Schoenitz and Edward L. Dreizin, Structure and properties of Al-Mg mechanical alloys, J. Mater. Res., Vol. 18, No. 8, Aug 2003, p1827-1836.

[19] S. Lee, A. Utsunomiya, H. Akamatsu, K. Neishi, M. Furukawa, Z. Horita, T.G. Langdon, Influence of scandium and zirconium on grain stability and superplastic ductilities in ultrafine-grained Al-Mg alloys, Acta Materialia Volume 50, Issue 3, 8 February 2002, Pages 553-564

[20] Yulin Liu, Yimeng Sun, Li Zhang, Yuhua Zhao, Jijie Wang and Chunzhong Liu. Microstructure and Mechanical Properties of Al-5Mg-0.8Mn Alloys with Various Contents of Fe and Si Cast under Near-Rapid Cooling, Metals, 2017, 7, 428; doi:10.3390/met7100428

[21] Y. Liu, L. Luo, C. Han, L. Ou, J. Wang, C. Liu, Effect of Fe, Si and cooling rate on the formation of Fe-and Mn-rich intermetallics in Al-5Mg-0.8Mn alloy, J. Mater. Sci. Technol. 32 (2016) 305-312.

[22] Y. Liu, G. Huang, Y. Sun, L. Zhang, Z. Huang, J. Wang, C. Liu, Effect of Mn and Fe on the formation of $\mathrm{Fe}$-and $\mathrm{Mn}$-rich intermetallics in $\mathrm{Al}-5 \mathrm{Mg}-\mathrm{Mn}$ alloys solidified under near-rapid cooling, Materials (Basel). 9 (2016) 88.

[23] H Yang, S Ji, Z Fan, Effect of heat treatment and Fe content on the microstructure and mechanical properties of die-cast Al-Si-Cu alloys, Materials \& Design 85, 2015, 823832

[24] A. Hamasaiid, M.S. Dargusch, C.J. Davidson, S. Tovar, T. Loulou, F. Rezai-Aria, G. Dour, Effect of mold coating materials and thickness on heat transfer in permanent mold casting of aluminum alloys, Metall. Mater. Trans. A. 38 (2007) 1303-1316.

[25] K.L. Kendig, D.B. Miracle, Strengthening mechanisms of an Al-Mg-Sc-Zr alloy, Acta Mater. 50 (2002) 4165-4175. 
[26] Rongde Li, Jianchao Ma, Zhenping Zhou, Effect of Mn content on microstructure of eutectic Al-2\%Fe, Hot Working Tech. (2004) 14-16.

[27] J. Grin, U. Burkhardt, M. Ellner, K. Peters, Refinement of the Fe4Al13 structure and its relationship to the quasihomological homeotypical structures, Zeitschrift Fuer Krist. 209 (1994) 479-487.

[28] J.G. Barlock, L.F. Mondolfo, Structure of Some Aluminum-iron-magnesiummanganese-silicon alloys, Zeitschrift Fur Met. 66 (1975) 605-611. 

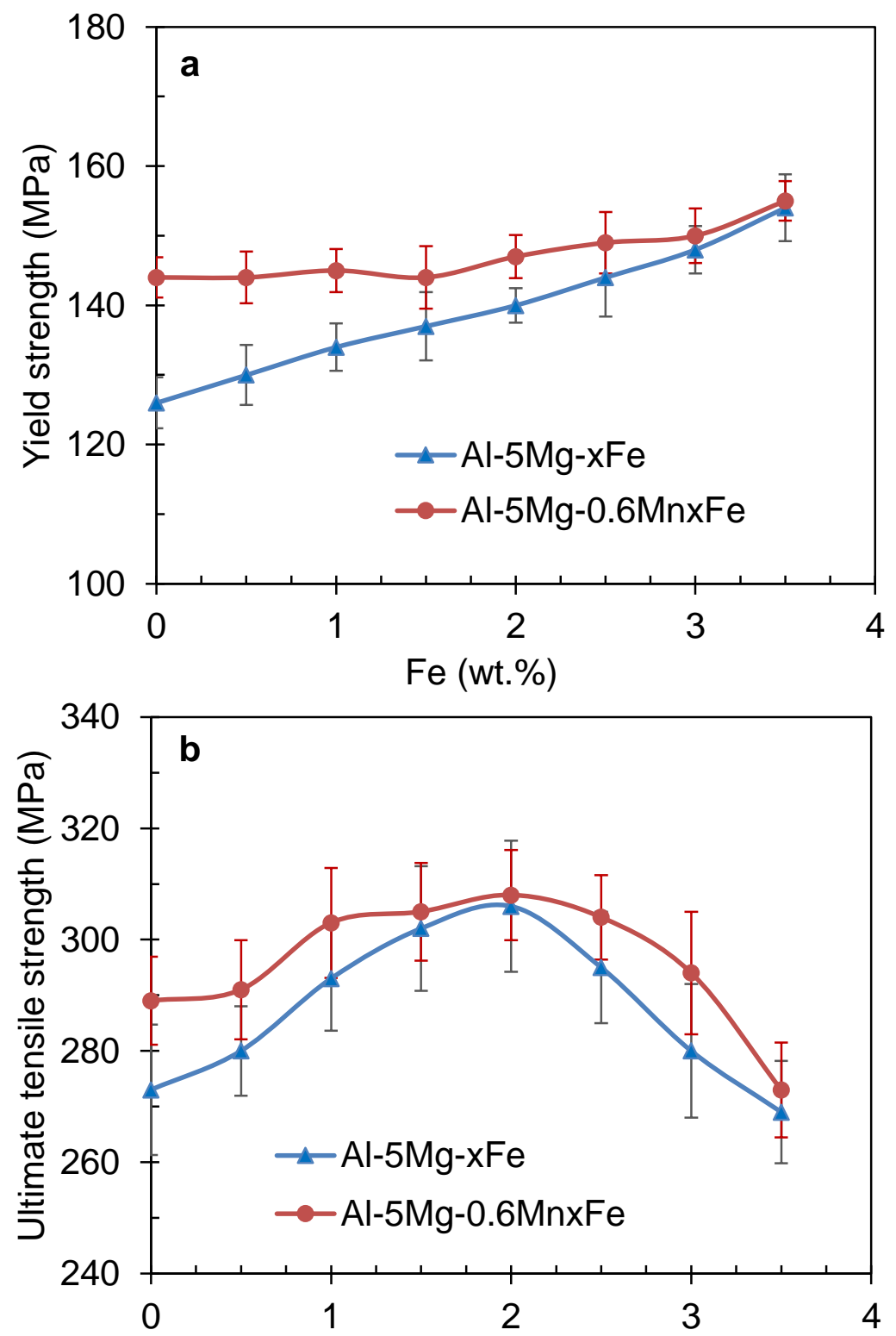

$\mathrm{Fe}(\mathrm{wt} . \%)$

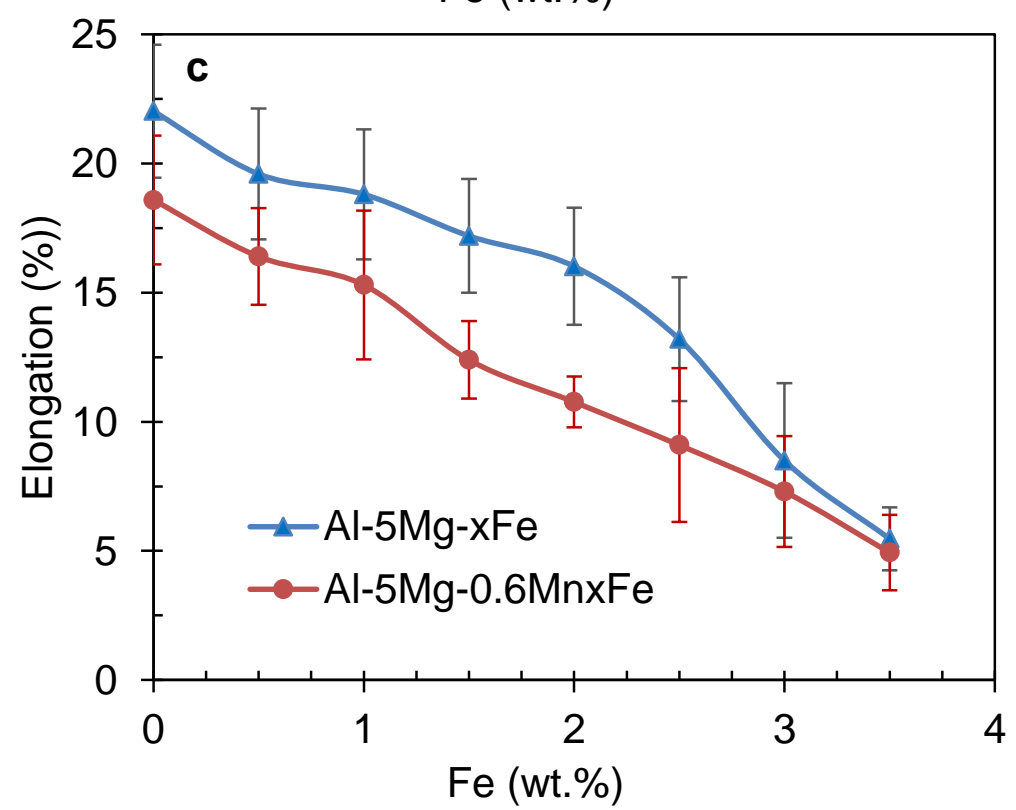

Figure 1 (a) Yield strength, (b) ultimate tensile strength and (c) elongation of Al$5 \mathrm{wt} . \% \mathrm{Mg}-\mathrm{xFe}$ and $\mathrm{Al}-5 \mathrm{wt} . \% \mathrm{Mg}-0.6 \mathrm{wt} . \% \mathrm{Mn}-\mathrm{xFe}$ alloys under as-cast condition. 


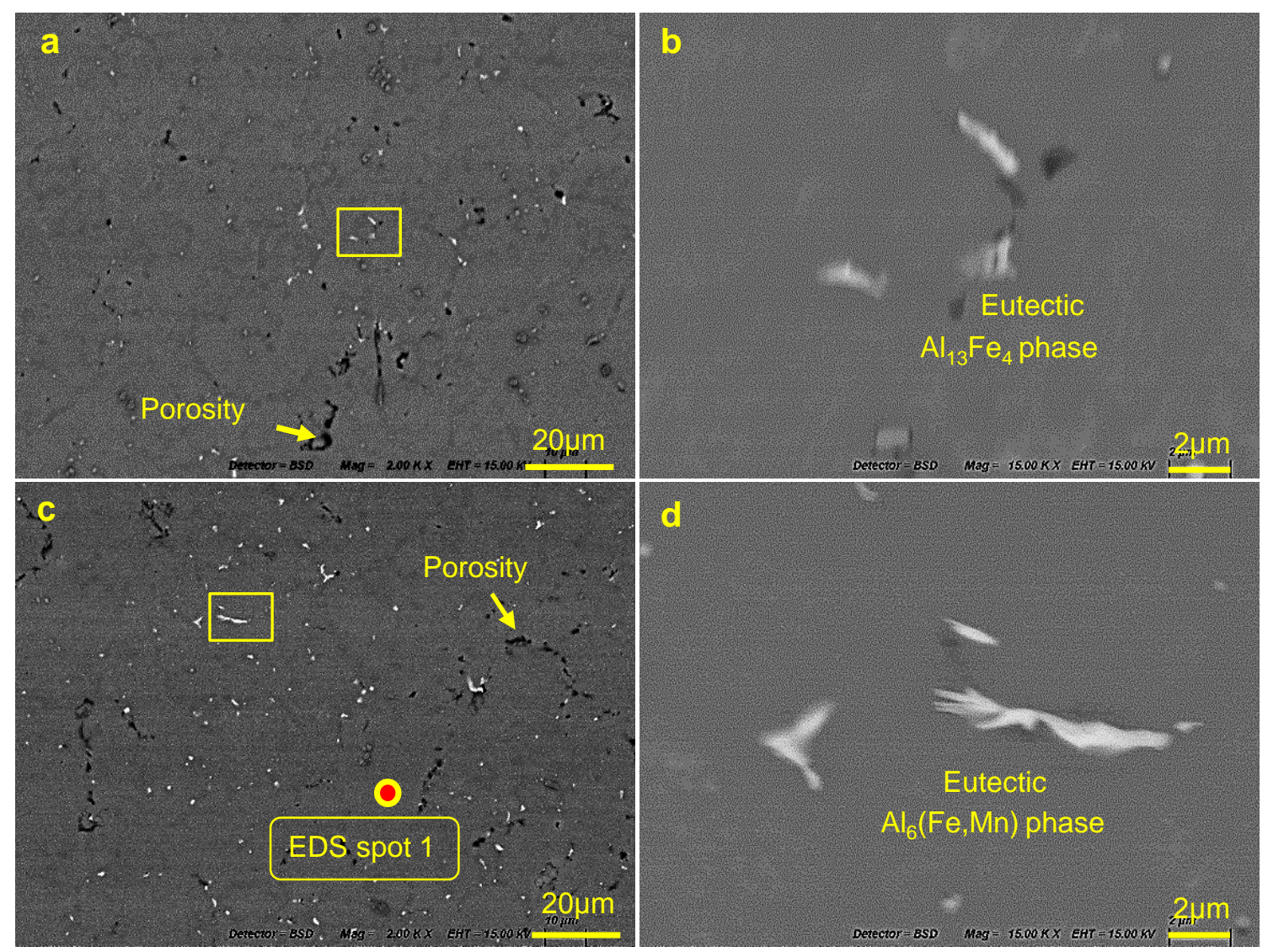

Figure 2 Backscattered SEM micrographs showing the microstructure of (a,b) Al5wt.\% Mg and (c,d) Al-5wt.\%Mg-0.5wt.\%Mn alloys. b and d are the enlarged magnification of the marked area in a and c, respectively. 


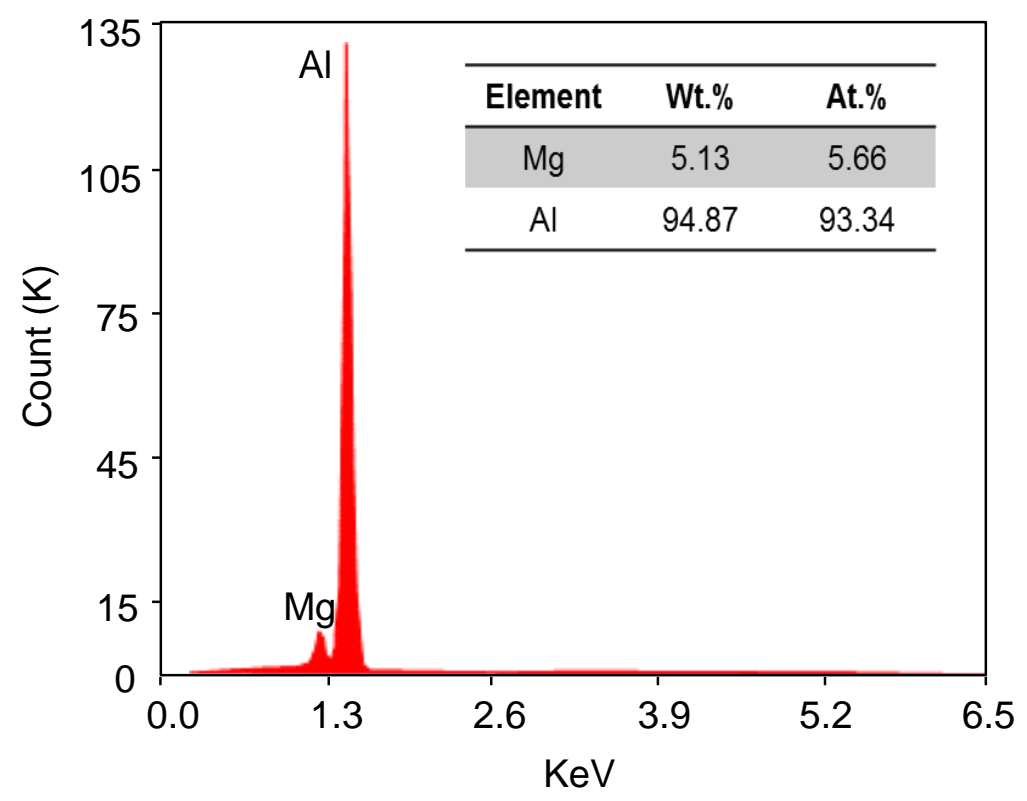

Figure $3 \mathrm{EDS}$ analysis result of $\alpha-\mathrm{Al}$ grain in $\mathrm{Al}-5 \mathrm{wt} . \% \mathrm{Mg}-0.5 \mathrm{wt} . \% \mathrm{Mn}$ alloy (spot 1 in Figure 1c). 


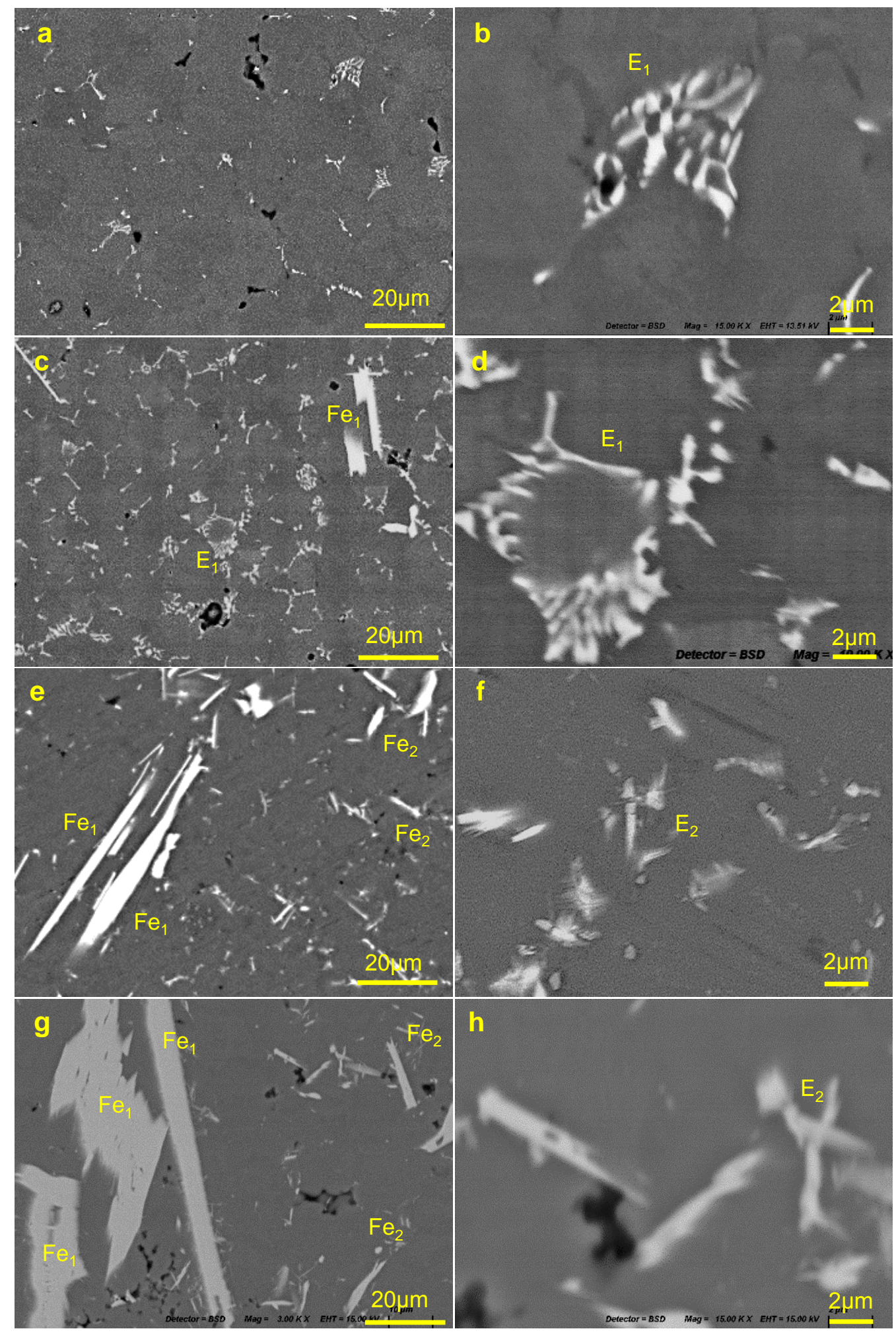

Figure 4 Backscattered SEM micrographs showing the microstructure of Al5wt.\%Mg-xFe alloys: (a,b) $\mathrm{x}=0.5$, (c,d) $\mathrm{x}=1.5$, (e,f) $\mathrm{x}=2.5$ and $(\mathrm{g}, \mathrm{h}) \mathrm{x}=3.5$. 


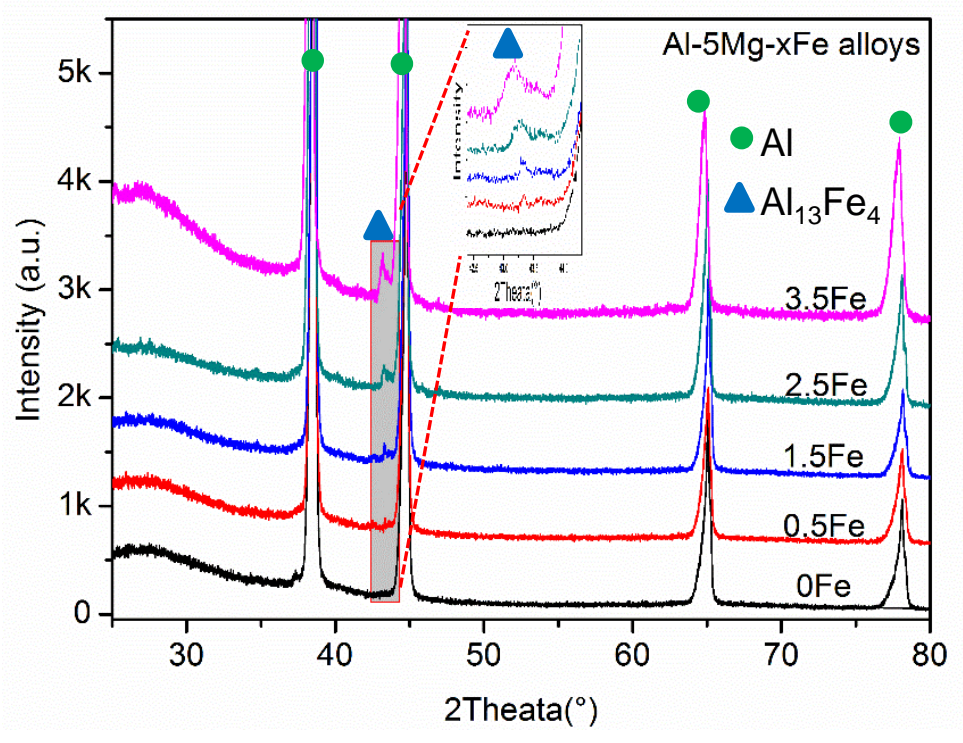

Figure $5 \mathrm{XRD}$ patterns of the Al-5wt. $\% \mathrm{Mg}-\mathrm{xFe}$. 


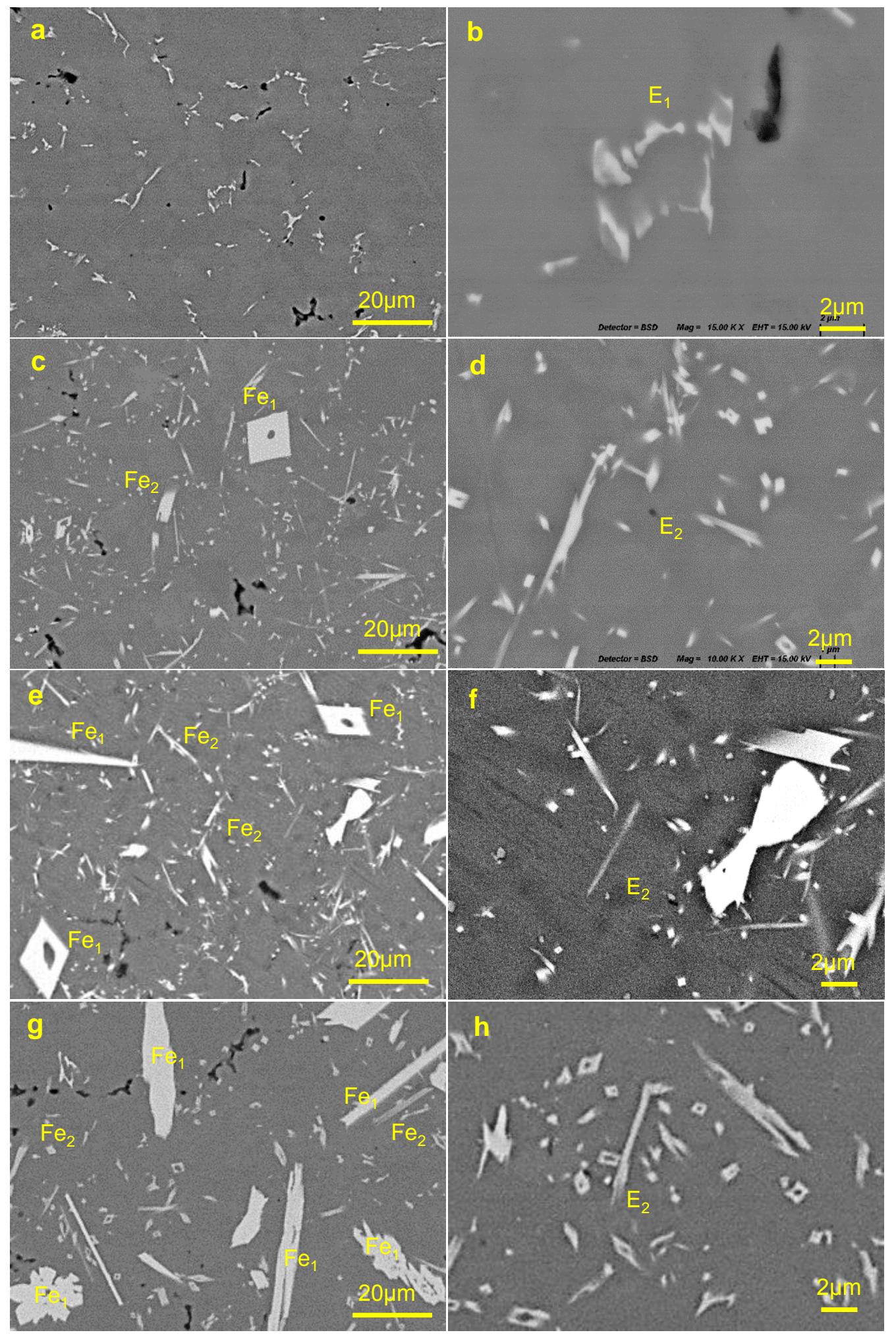

Figure 6 Backscattered SEM micrographs showing the microstructure of Al5wt.\%Mg-0.6wt.\%Mn-xFe alloys: $(\mathrm{a}, \mathrm{b}) \mathrm{x}=0.5$, (c,d) $\mathrm{x}=1.5,(\mathrm{e}, \mathrm{f}) \mathrm{x}=2.5$ and $(\mathrm{g}, \mathrm{h})$ $\mathrm{x}=3.5$. 


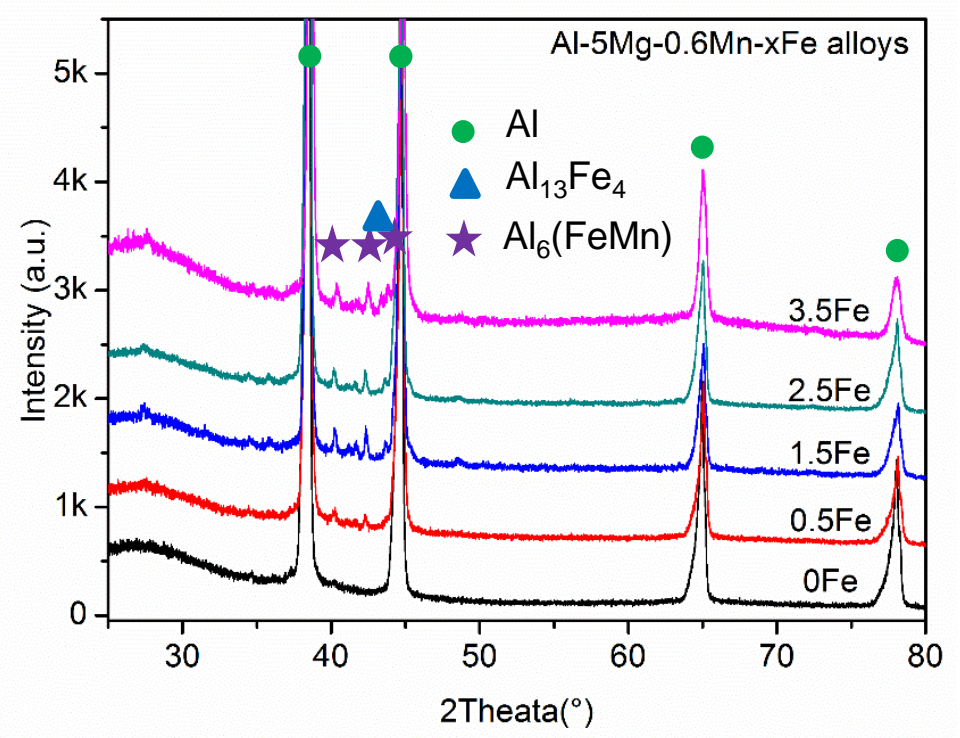

Figure 7 XRD patterns of the Al-5wt. $\% \mathrm{Mg}-0.6 \mathrm{wt} . \% \mathrm{Mn}-\mathrm{xFe}$. 

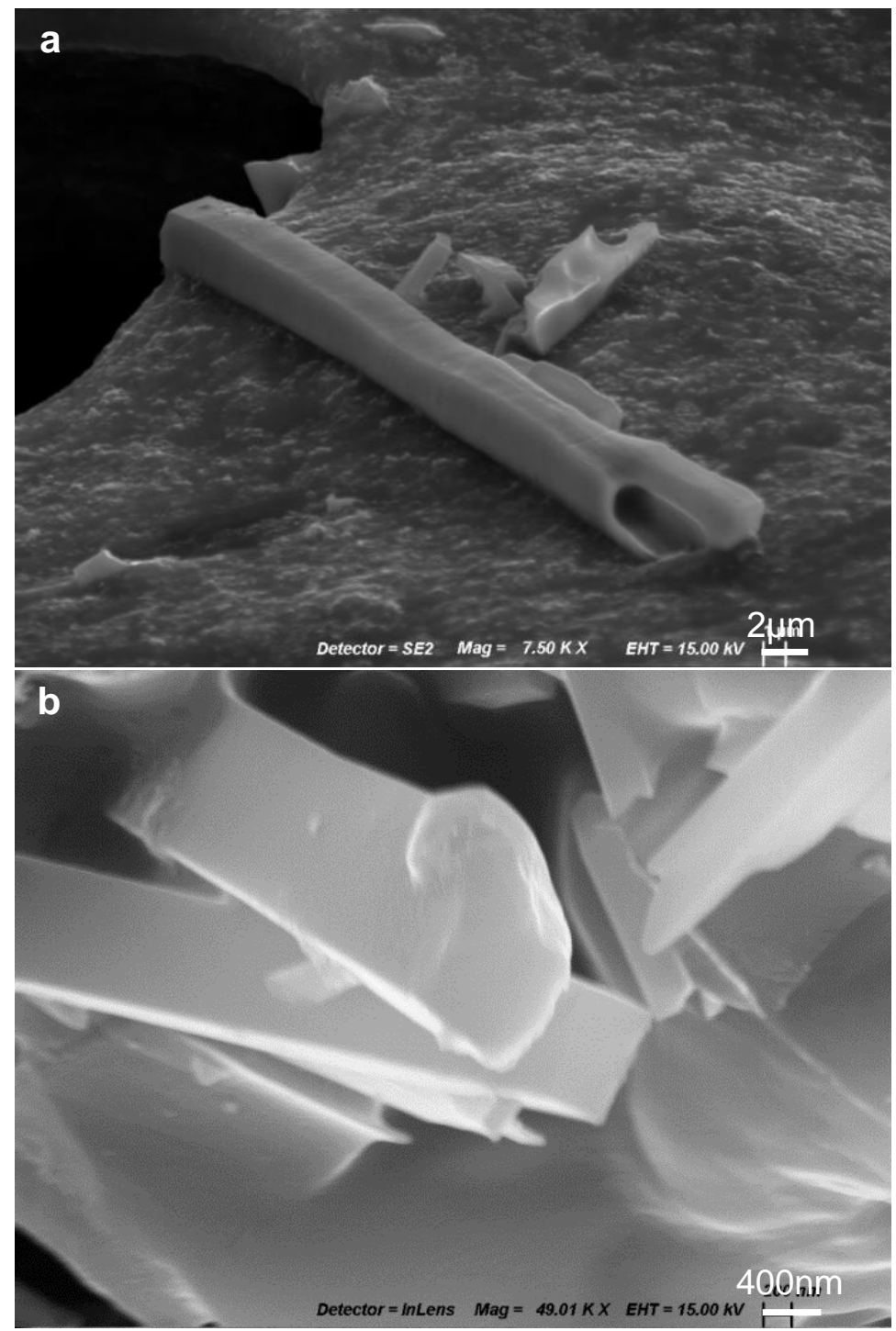

Figure 8 SEM micrographs showing the 3D morphology of (a) primary and (b) eutectic $\mathrm{Al}_{6}(\mathrm{Fe}, \mathrm{Mn})$ phase in $\mathrm{Al}-\mathrm{Mg}-\mathrm{Fe}-\mathrm{Mn}$ alloys. 

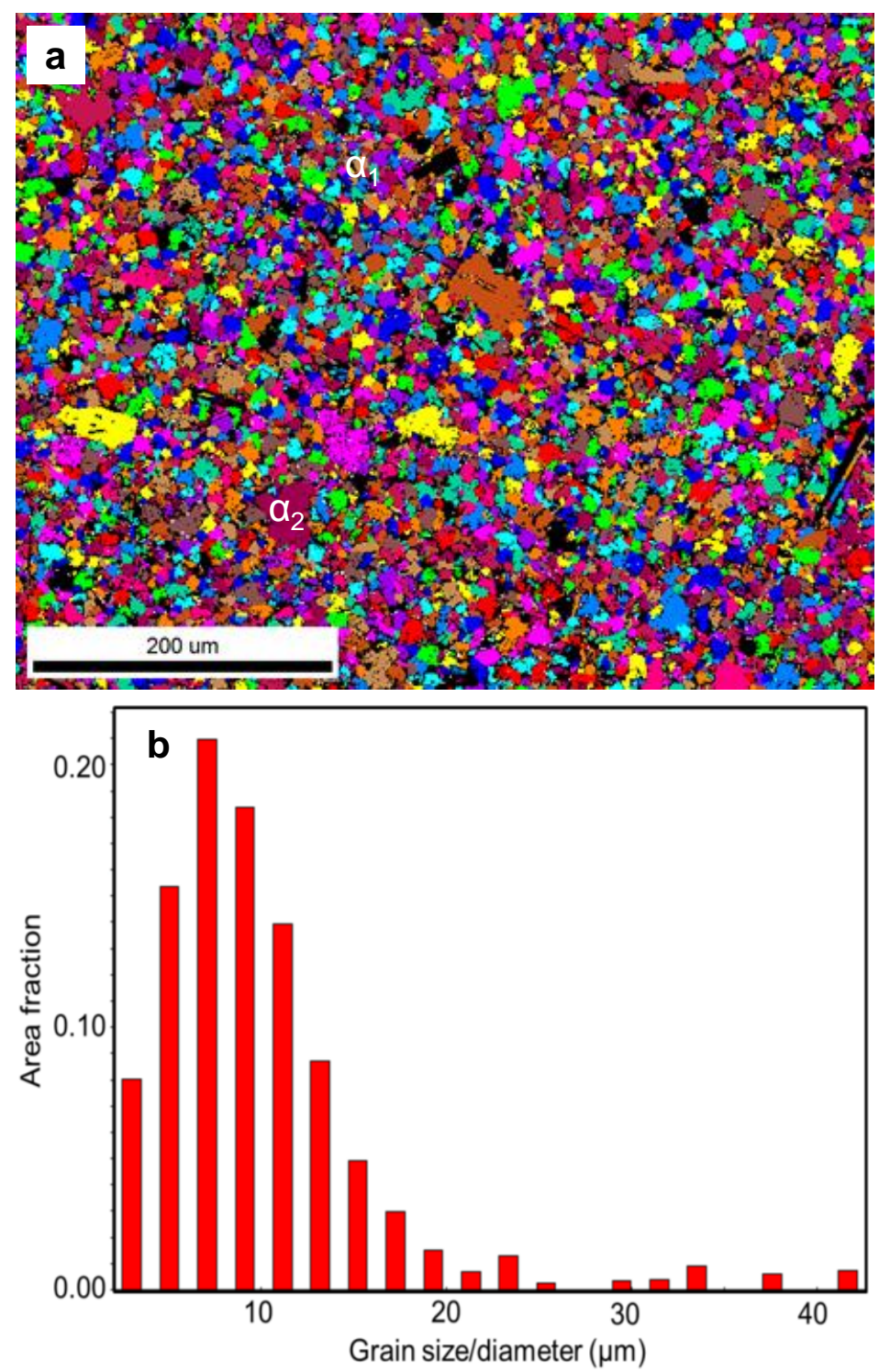

Figure 9 (a) EBSD IPF, (b) distribution of $\alpha$-Al grain size of Al-5wt.\%Mg-0.6wt.\%Mn-2wt.\%Fe alloy. The black part in (a) is $\mathrm{Al}_{6}(\mathrm{Fe}, \mathrm{Mn})$ phase. 

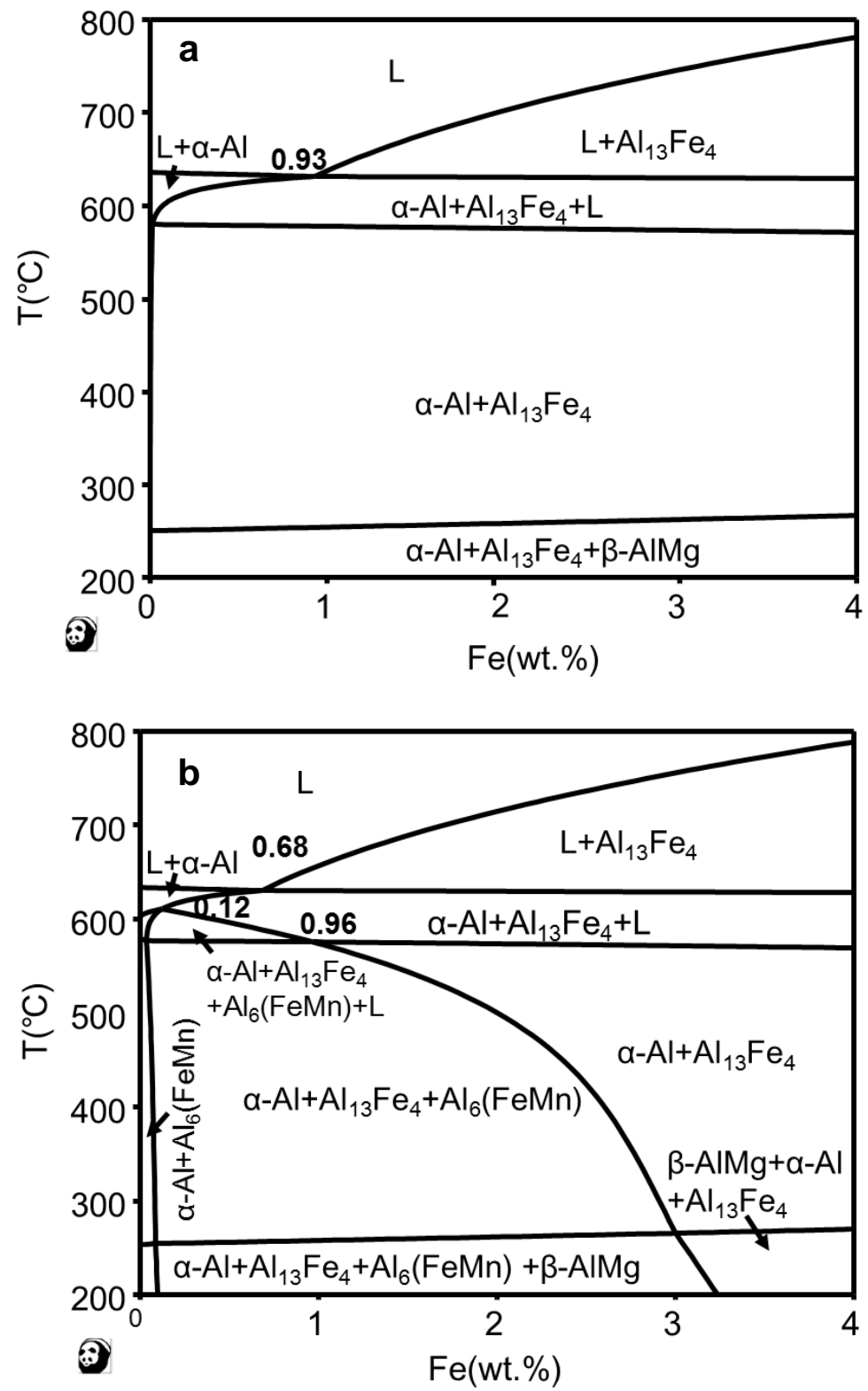

Figure 10 The cross section of equilibrium phase diagram of (a) Al-5wt.\% $\mathrm{Mg}-\mathrm{xFe}$ and (b) Al-5wt.\%Mg-0.6wt.\%Mn-xFe alloys calculated by Pandat software. 

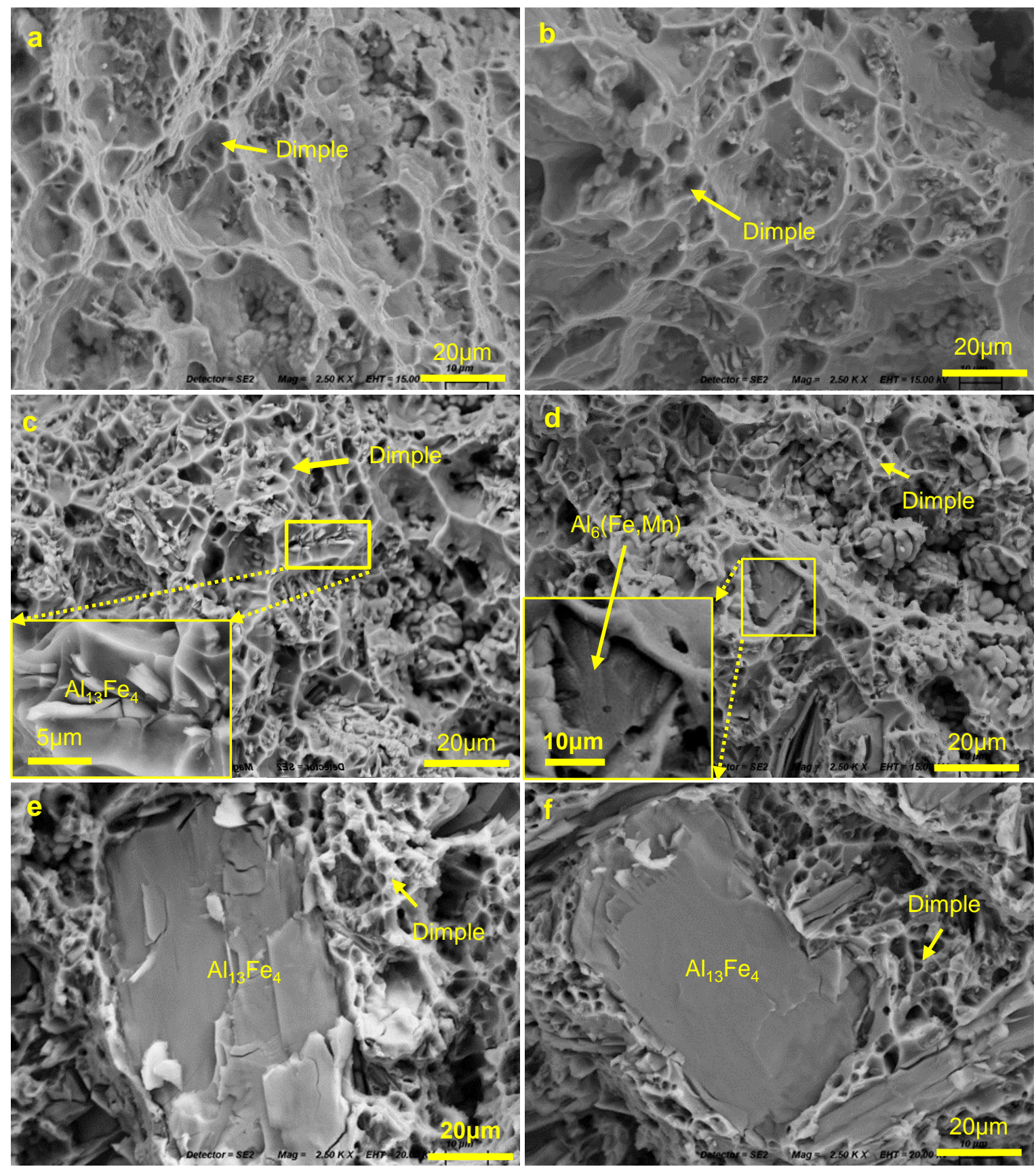

Figure 11 SEM micrographs showing the fracture surfaces of (a,c,e) Al-5wt.\% Mg-xFe and (b,d,f) Al-5wt.\%Mg-0.6wt.\%Mn-xFe alloys: (a, b) $x=0,(c, d) x=2.0$ and $(e, f) x=3.5$. 


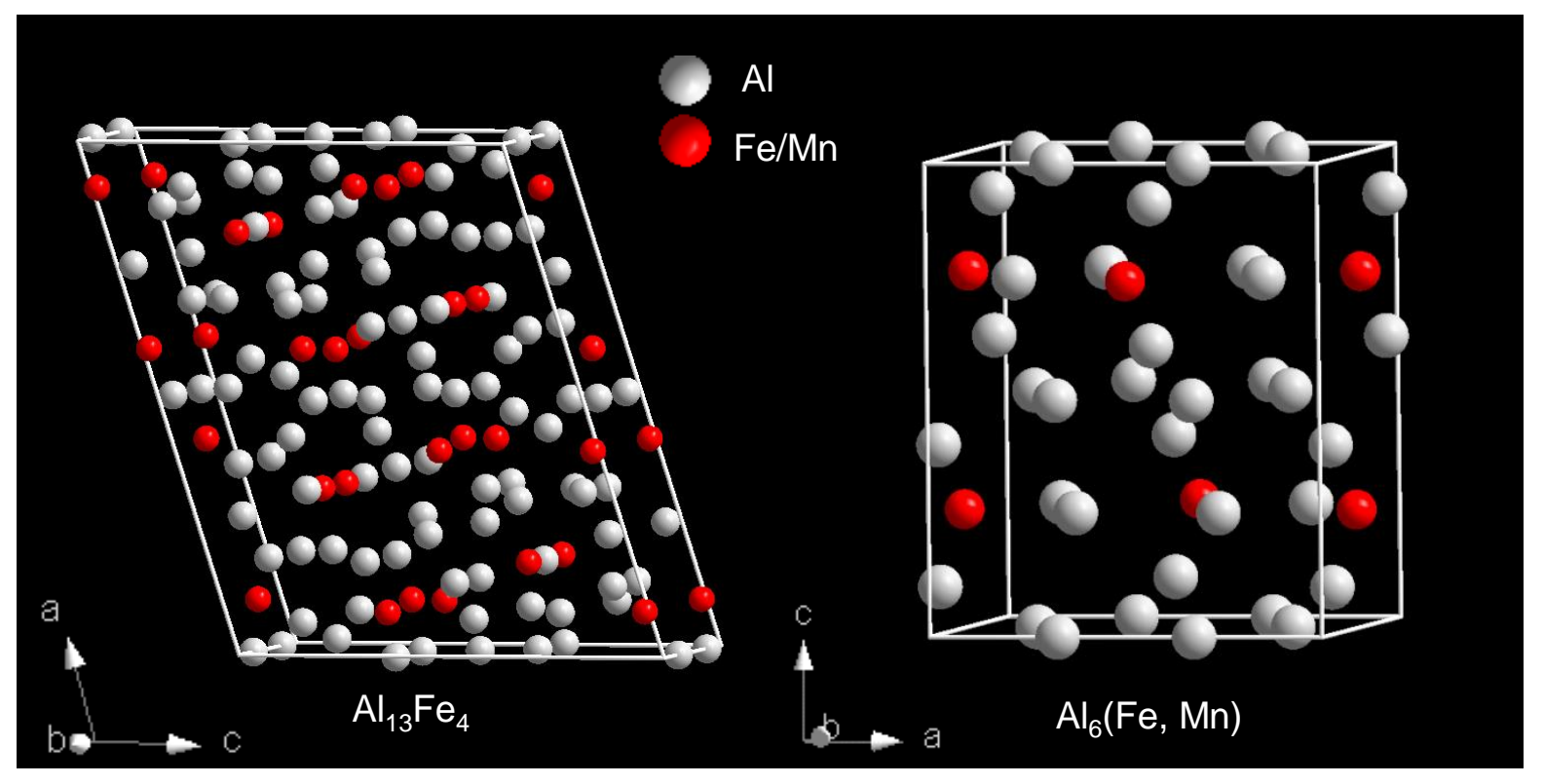

Figure 12 Crystal structure of $\mathrm{Al}_{13} \mathrm{Fe}_{4}$ and $\mathrm{Al}_{6}(\mathrm{Fe}, \mathrm{Mn})$ phase. 
Table 1 The chemical compositions of Al-5wt.\%Mg-xFe and Al-5wt.\%Mg-0.6wt.\%Mn-xFe alloys analysed by ICP-AES.

\begin{tabular}{lcllll}
\hline Alloy & $\mathrm{Mg}$ & $\mathrm{Fe}$ & $\mathrm{Mn}$ & others & $\mathrm{Al}$ \\
\hline Al-Mg-Fe & $5 \pm 0.2$ & varied $^{\mathrm{a}}$ & $0.6 \pm 0.03$ & $<0.05$ & Bal. \\
& & & & & \\
Al-Mg-Fe-Mn & $5 \pm 0.2$ & varied $^{\mathrm{b}}$ & $0.6 \pm 0.03$ & $<0.05$ & Bal. \\
\hline
\end{tabular}

${ }^{a}$ Actual Fe contents were measured to be $0.09,0.53,1.03,1.48,1.91,2.54,3.02$ and 3.48, respectively.

${ }^{\mathrm{b}}$ Actual Fe contents were measured to be 0.10, 0.47, 1.10, 1.55, 1.95, 2.48, 2.97 and 3.51, respectively. 
Table 2 Crystal parameters of $\mathrm{Al}_{13} \mathrm{Fe}_{4}$ and $\mathrm{Al}_{6}(\mathrm{Fe}, \mathrm{Mn})$ cell.

\begin{tabular}{cccccc}
\hline Phase & $\begin{array}{c}\text { Crystal } \\
\text { System }\end{array}$ & Space Group & Cell Volume & $\mathrm{N}_{\mathrm{FeMn}}$ & $\mathrm{V}_{\mathrm{FeMn}}$ \\
\hline $\mathrm{Al}_{13} \mathrm{Fe}_{4}$ & monoclinic & $\mathrm{C} 12 / \mathrm{m} 1(12)$ & $1486.88 \AA^{3}$ & 20 & $74.34 \AA^{3}$ \\
$\mathrm{Al}_{6}(\mathrm{Fe}, \mathrm{Mn})$ & orthorhombic & $\mathrm{Cmcm}(63)$ & $430.36 \AA^{3}$ & 4 & $107.59 \AA^{3}$ \\
\hline
\end{tabular}

